Printed in Great Britain

\title{
THE AGE AND GROWTH OF THE SCALLOP, PECTEN MAXIMUS (L.), IN MANX WATERS
}

\author{
By JAMES MASON \\ Marine Laboratory, Aberdeen
}

(Text-figs. I-9)

\section{MATERIAL AND METHODS}

An important fishery for the scallop, Pecten maximus (L.), is carried on during the winter months round the Isle of Man. A knowledge of the age and growth of the scallop would be useful should conservation become necessary with regard to the fishery.

Regular samples of scallops were obtained at roughly weekly or fortnightly intervals throughout the period October $1950-O c t o b e r 1952$ from two areas off Port Erin. These were one-quarter to one-half a mile off Bay Fine (Station I) and one-quarter to one-half a mile off Bradda Head (Station 2) respectively, the depth in each area being $13-16 \mathrm{fm} .(23 \cdot 8-29 \cdot 3 \mathrm{~m}$ ) (see chart, Fig. I). A few samples were obtained from each of three other stations, in 9-II fm. (16.5-20. I m) off Gob-yn-Ushtey (Station 3), in I9-20 fm. (34.7$36 \cdot 6 \mathrm{~m}$ ) on the Breast (Station 4), and in $28-29 \mathrm{fm}$. $(5 \mathrm{I} \cdot 2-53 \cdot 0 \mathrm{~m}) 3 \frac{1}{2}$ miles W.S.W. of the Chicken Rock (Station 5).

Excepting a few from commercial fishermen, all samples were taken by the research vessels William Herdman, Cypris and Runa of the Marine Biological Station, Port Erin, towing toothed scallop dredges. The bag of the commercial dredge used by the $64 \mathrm{ft}$. R.V. William Herdman had a belly of rings of $\frac{1}{4}$ in. $(6 \cdot 4 \mathrm{~mm})$ steel, with an internal diameter of $3 \frac{1}{4} \mathrm{in}$. $(82 \mathrm{~mm})$, joined together by small steel ties, and a back of sisal netting measuring 2-3 in. $(5 \mathrm{I}-76 \mathrm{~mm})$ from knot to knot. The cross-bar was $6 \mathrm{ft}$. $(\mathrm{I} \cdot 83 \mathrm{~m})$ long and carried teeth, $3 \frac{1}{2}$ in. $(89 \mathrm{~mm})$ apart, which protruded $1 \frac{3}{4}$ in. $(44 \mathrm{~mm})$. Such a dredge captures only a few small scallops, and it was assumed that the size of the rings and mesh of the bag were the effective factors in selection. A smaller dredge was fitted with an inner lining of $\frac{3}{8}$ in. $(9.5 \mathrm{~mm})$ mesh shrimp netting in an attempt to catch smaller members of the scallop population. This small-mesh dredge had a cross-bar $4 \mathrm{ft}$. ( $(\mathrm{r} \cdot 22 \mathrm{~m})$ long, carrying teeth 3 in. $(76 \mathrm{~mm})$ apart which protruded 2 in. (5I mm). The Cypris and Runa, which are considerably smaller than the William Herdman, used $4 \mathrm{ft}$. ( $(1 \cdot 22 \mathrm{~m})$ and $3 \mathrm{ft}$. (0.91 m) dredges, both commercial and small-mesh. Baird \& Gibson (1956) have since suggested that tooth-spacing is the effective agent in size selection, but the small-mesh dredge, nevertheless, took numbers of small 
scallops by digging deep into the bottom and filling up with gravel and shells, thus acting as a complete bottom sampler.

Individual hauls varied in duration from 7 to $20 \mathrm{~min}$. and in speed of towing from 2 knots (by the Cypris and Runa) to 3 knots (by the William Herdman).

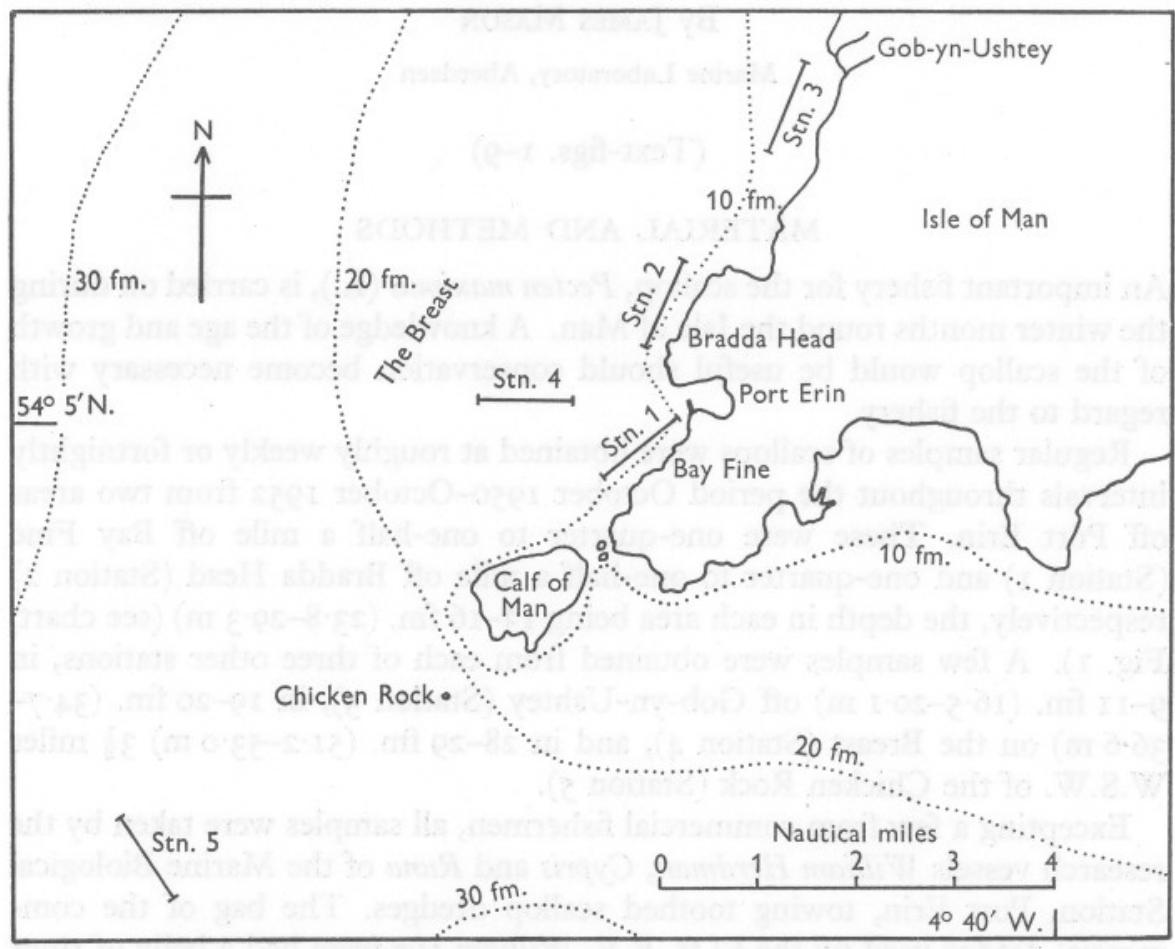

Fig. I. Chart of S.W. Isle of Man, showing the sampling stations.

Depth contours in fathoms.

Various measurements were made on the scallops caught. The over-all length (anterior-posterior axis), breadth (dorso-ventral axis), and thickness (lateral axis) were measured on a specially designed measuring board. The over-all length and breadth are in reality the length and breadth of the rounded, or right, valve of the shell, which overlaps the flat, or left, valve. Dividers were used to measure the distance from the umbo to the edge of the flat valve, and to each of the annual growth rings (see below) on the flat valve along the dorso-ventral axis. All measurements were to the nearest millimetre below the value shown on the scale. 


\section{The growth-rings}

\section{AGE-ANALYSIS}

The shell of Pecten maximus bears distinct concentric growth-rings, which are white in colour and translucent. They show more clearly on the reddish brown flat valve than on the white round valve. They occur regularly and in approximately the same position on most shells.

In addition, the shell bears numerous regularly occurring concentric striae, $0.1-0.3 \mathrm{~mm}$ apart, which are prominent and raised over most of the shell, but less so in a slightly concave area within $20-25 \mathrm{~mm}$ of the umbo. These striae are the result of the manner in which the shell is enlarged by the deposition of new material at its edge (Coker, Shira, Clark \& Howard, I92I), so that each one represents the edge of the shell at the time of its deposition. The striae tend to become worn on the round valve of the shell, which is in contact with the sea-bed, and, on account of this, they were examined on the upper, flat valve.

The growth-rings are $\frac{1}{2} \mathrm{~mm}$ or less wide, and are made up of striae which are crowded together about $0.05 \mathrm{~mm}$ apart and less prominent than elsewhere. Immediately outside a ring, on the side away from the umbo, the striae become more raised, assume a pale brown colour, and become farther (about $0.3 \mathrm{~mm}$ ) apart. After a few millimetres the striae take on a darker hue, and become gradually closer together until, just before the next ring, they are about $0.1 \mathrm{~mm}$ apart. This description applies to the shell between the second and third rings from the umbo. Farther from the umbo, both the growth rings and the striae are somewhat closer together, but a similar series of changes is seen.

Dakin (1909) considered that the growth-rings may indicate the age of the shell. Priol (1930) and Elmhirst (1945) also considered that they were laid down annually. Tang (194I), working on P. maximus at Port Erin, found that a ring is laid down in April, May or June, and said that, while it is not certain that all rings are laid down at yearly intervals, there is probably a good deal of agreement between the number of rings and the age of the scallop. I examined the edge of the flat valve of the shell throughout the year, and found that only one ring is laid down each year, in the spring.

The growth-ring is narrow and is laid down slowly, taking perhaps several weeks, but its deposition is followed at once by rapid growth, so that any growth-ring near the edge of the shell has very recently been laid down. In each month the number of scallops was noted which had a ring within $3 \mathrm{~mm}$ of the edge of the flat valve. Growth becomes slower in older scallops, and the later growth-rings become close together and difficult to distinguish, and so only scallops which had fewer than five growth-rings were included. The results are shown in Fig. 2. The somewhat low percentages are due to the long period of time (March-May) during which rings are laid down, so that some scallops have acquired more than $3 \mathrm{~mm}$ of new growth before others have commenced to lay down their ring. 
Evidence that only one ring was laid down each year was afforded also by a tagging experiment. Six living tagged scallops were recaptured which had spent one spring in the sea, and each of these had one more ring than when it was released. Of thirty-seven scallops recaptured before they had spent a spring in the sea, none had acquired a further ring. Occasionally a disturbancering was found on these scallops where the edge of the shell was at the time of tagging, being probably caused by a retraction of the mantle edge away from the edge of the shell during tagging. Such a ring differs from an annual ring in that it has no small, crowded striae, and that the striae on either side of it are equally spaced. Such false rings also occur occasionally in nature.

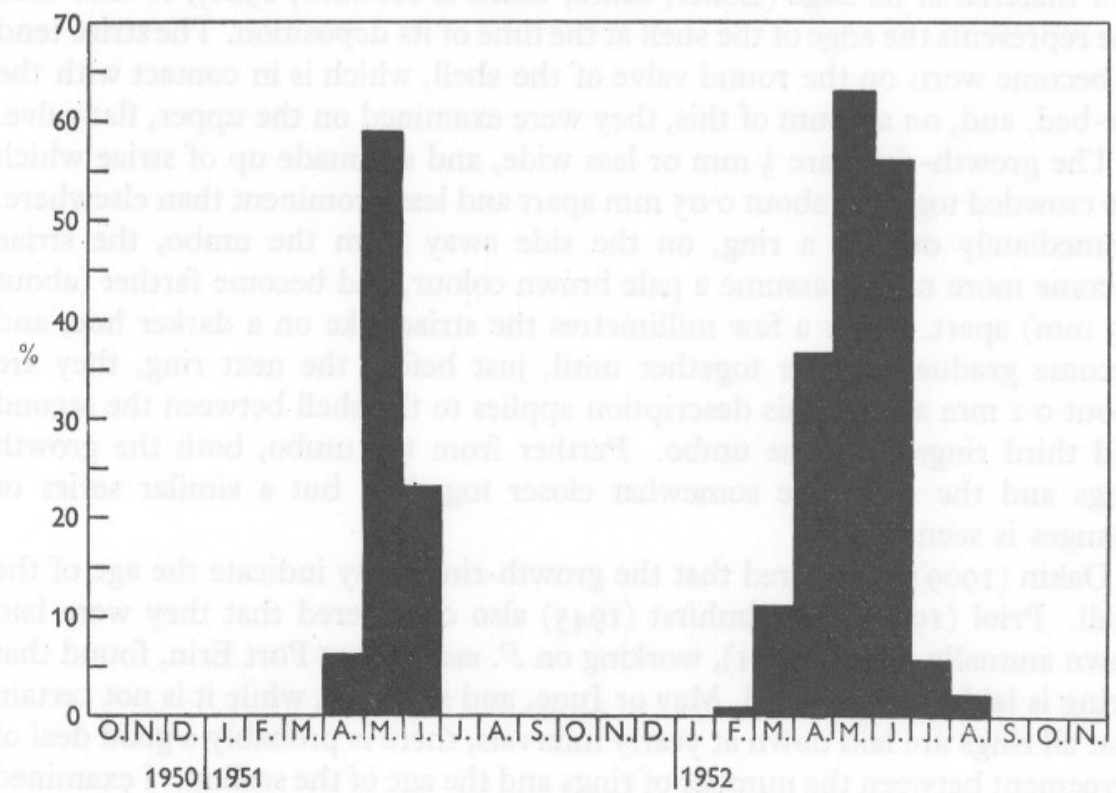

Fig. 2. Percentages of scallops with fewer than five growth-rings, which had a growth-ring within $3 \mathrm{~mm}$ of the edge of the shell (3592 scallops examined).

Gibson (1956), by means of a similar tagging experiment, obtained evidence of the annual nature of the growth-rings on the shell of $P$. maximus in Irish waters.

In subsequent pages, the area of shell between two successive annual growth-rings, or between the umbo and the first ring, will be called a growthband. A scallop is aged by the number of growth-rings and the presence or absence of new growth outside the outermost ring. Thus $5+$ indicates that the shell has five rings, with new growth outside the fifth, while 4 indicates that the fourth ring has just been laid down at the edge of the shell. 


\section{Length of life}

Tang (I94I) recorded a scallop, captured off Port Erin, which had twentytwo growth-rings; the oldest one I caught had eighteen rings.

\section{GROWTH}

\section{THE FIRST GROWTH-BAND}

If the size-frequency of the first growth-band is plotted, a bimodal distribution is obtained; Bradda and Bay Fine scallops with from I to I 5 rings were used for this investigation. The results are presented in Fig. 3, the widths being in $2 \mathrm{~mm}$ groups. The modal values are 19 and $39 \mathrm{~mm}$ respectively, and

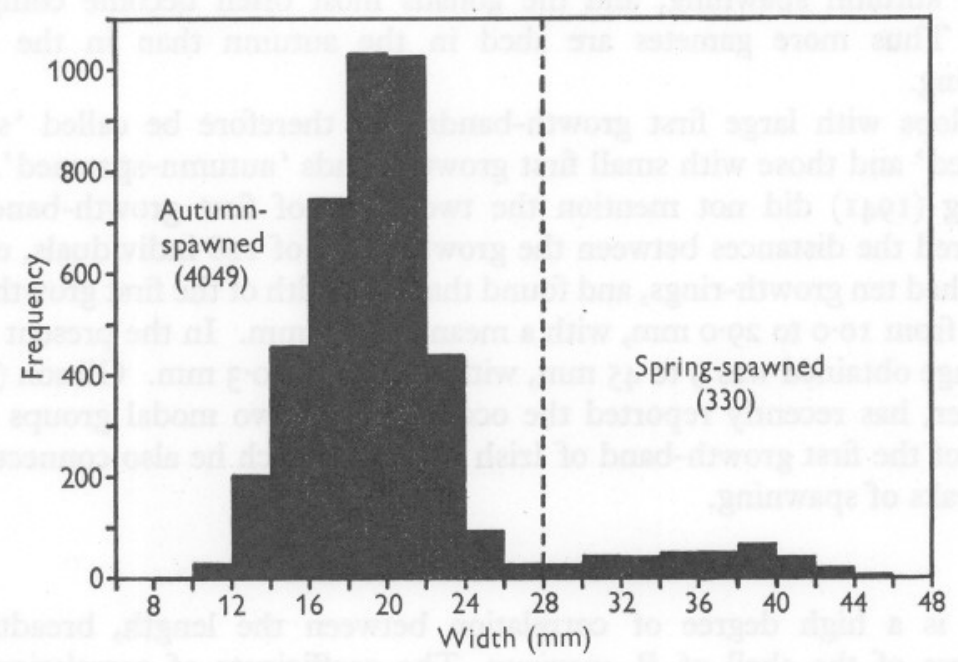

Fig. 3. Width-frequency of the first growth-band.

the curve is divided arbitrarily at $28 \mathrm{~mm}$, giving two groups of scallops, a majority with small, and a minority with large, first growth-bands. Of 4379 scallops examined, 4049 , or $92.5 \%$ had small, and 330 , or $7.5 \%$ had large, first growth-bands.

The two types of first growth-band can be correlated with the breeding cycle of the scallop. P. maximus in Manx waters has two main spawnings each year, a spring spawning in April or May and an autumn spawning in late August or September, while there is a small summer spawning in July or early August. Growth of the scallop ceases in December, and the resumption of growth in spring results in the appearance of the growth-ring (see later, p. 485). Spring-spawned scallops would thus grow for a greater length of time before the first cessation of growth than would autumn- 
spawned individuals. It is suggested that most of the scallops forming the minor group, those with large first growth-bands, arise from the spring spawning, and that most of those forming the major group, those with small first growth-bands, arise from the autumn spawning, while a few of the latter probably arise from the small summer spawning.

Although there are many possible factors which can influence the success of a brood, the difference in the numbers of scallops constituting the two groups can to some extent be accounted for by the amount of spawn released in each spawning. Only those which have just deposited, or are about to deposit, their fourth or any subsequent growth-ring, take part in the spring spawning, and their gonads become only partially spent. On the other hand, mature scallops of all ages (those with two or more growth-rings) take part in the autumn spawning, and the gonads most often become completely spent. Thus more gametes are shed in the autumn than in the spring spawning.

Scallops with large first growth-bands will therefore be called 'springspawned' and those with small first growth-bands 'autumn-spawned'.

Tang (I94I) did not mention the two types of first growth-band. He measured the distances between the growth-rings of 128 individuals, each of which had ten growth-rings, and found that the width of the first growth-band varied from 10.0 to $29.0 \mathrm{~mm}$, with a mean of $19.0 \mathrm{~mm}$. In the present study, the range obtained was 9 to $45 \mathrm{~mm}$, with a mean of $20.3 \mathrm{~mm}$. Gibson (I956), however, has recently reported the occurrence of two modal groups in the width of the first growth-band of Irish scallops, which he also connects with two peaks of spawning.

\section{THE ANNUAL GROWTH RATE}

There is a high degree of correlation between the length, breadth and thickness of the shell of $P$. maximus. The coefficients of correlation were worked out on $6 \mathrm{I} 4$ scallops of all ages from $\mathrm{O}+$ to $\mathrm{I} 3+$. The coefficient of correlation between length and breadth is 0.9937 , and that between length and thickness is 0.9597 . Furthermore, a high degree of correlation exists between the length of the scallop and the breadth of the flat valve. The coefficient of correlation, worked out on 4I 4 scallops of all ages from $\mathrm{O}+$ to $\mathrm{I}_{3}+$, is 0.9954 . The scallop, in fact, grows proportionately in all dimensions, and retains virtually the same shape throughout its life, with the exception of a concavity on the upper valve during the first year or so. The annual increment of any one of these dimensions will, therefore, give a reliable indication of the rate of growth from one year to another.

Growth curves for P. maximus have been drawn, using Bradda and Bay Fine scallops, from the two following measurements: (i) position of successive annual growth-rings on the flat valve, and (ii) annual increase in length, breadth and thickness of the whole shell. 
(i) Since each growth-ring represents the position of the edge of the shell at the end of an annual growth period, it is possible to measure directly on the shell of any scallop, the breadth of the flat valve of that scallop at the end of each growth period in its life. By measuring the distances of the various growth-rings from the umbo it is possible to draw up a growth curve. The

\section{TABLE 1. MEAN DISTANCES OF THE GROWTH-RINGS FROM THE UMBO (FLAT VALVE)}

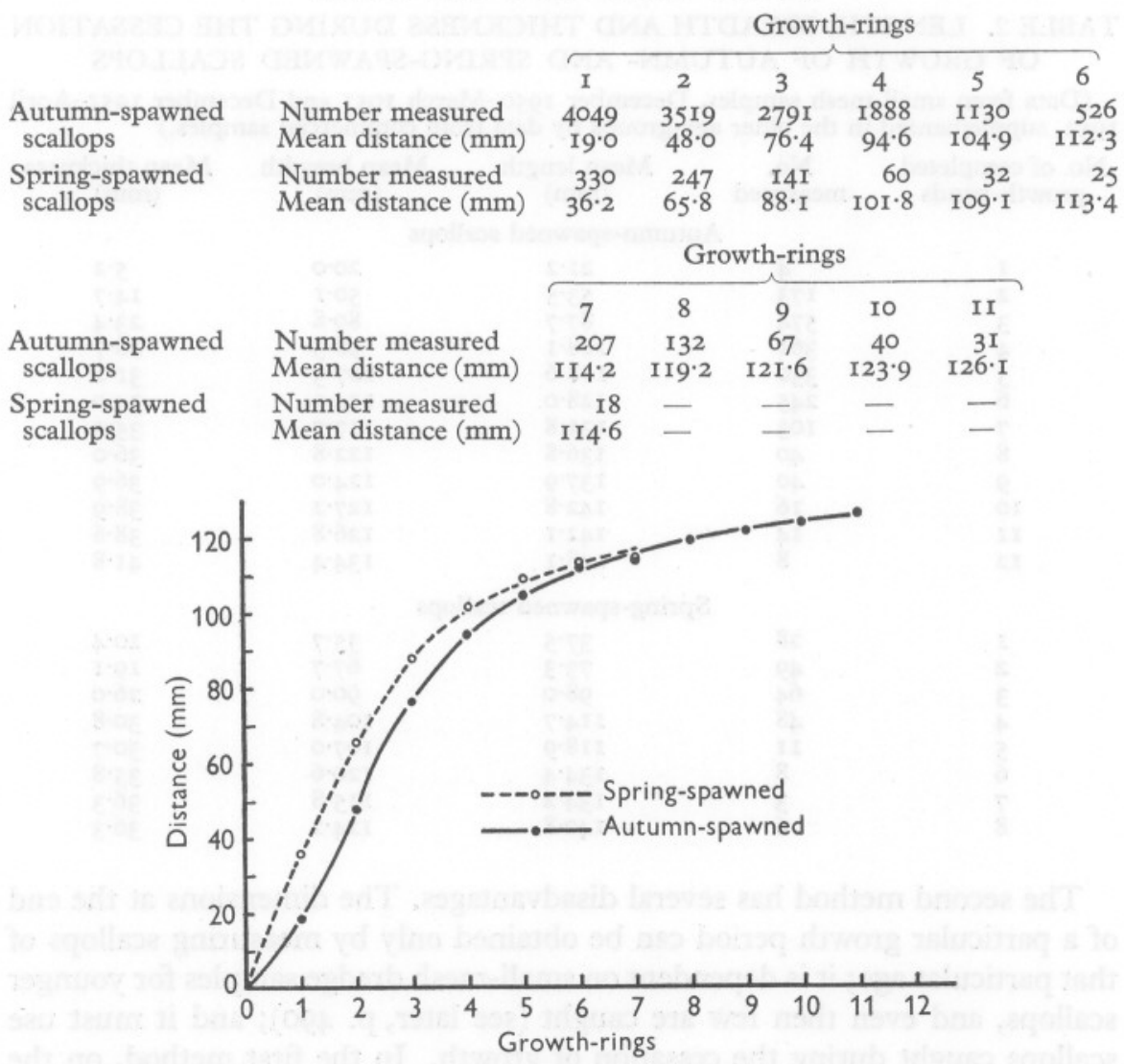

Fig. 4. Mean distances of the growth-rings from the umbo (flat valve).

results are shown in Table $I$ and Fig. 4. Only the first eleven rings were measured in autumn-spawned scallops because of the crowding together of the later rings and the small numbers of older scallops obtained. Few springspawned scallops were found with more than seven rings.

(ii) Growth curves were drawn by plotting the length, breadth and thickness of scallops measured during the cessations of growth in the winters of 
I950-5I and I95I-52; figures for the two winters were combined. No scallop was measured which showed new growth at the edge of the shell. In this method, a scallop which has no growth rings has completed its first growth period, one with one ring has completed two growth periods, and so on. Autumn-spawned scallops with eleven or fewer growth-rings and springspawned scallops with seven or fewer rings were used. The results are given in Table 2 and Fig. 5.

\section{TABLE 2. LENGTH, BREADTH AND THICKNESS DURING THE CESSATION OF GROWTH OF AUTUMN- AND SPRING-SPAWNED SCALLOPS}

(Data from small-mesh samples, December 1950-March I95I and December I95I-April I952, supplemented in the older age-groups by data from commercial samples.)

\begin{tabular}{|c|c|c|c|c|}
\hline $\begin{array}{l}\text { No. of completed } \\
\text { growth-bands }\end{array}$ & $\begin{array}{l}\text { No. } \\
\text { measured }\end{array}$ & $\begin{array}{l}\text { Mean length } \\
(\mathrm{mm})\end{array}$ & $\begin{array}{c}\text { Mean breadth } \\
(\mathrm{mm})\end{array}$ & $\begin{array}{l}\text { Mean thickness } \\
(\mathrm{mm})\end{array}$ \\
\hline \multicolumn{5}{|c|}{ Autumn-spawned scallops } \\
\hline I & 4 & $2 I \cdot 2$ & $20 \cdot 0$ & $5 \cdot 2$ \\
\hline 2 & I73 & 53.5 & $50 \cdot I$ & 14.7 \\
\hline 3 & 574 & $87 \cdot 7$ & $80 \cdot 8$ & 23.4 \\
\hline 4 & $36 i$ & $108 \cdot 1$ & $98 \cdot 5$ & $28 \cdot 7$ \\
\hline 5 & 330 & II $8 \cdot 6$ & $107 \cdot 3$ & $3 I \cdot 2$ \\
\hline 6 & 245 & $128 \cdot 0$ & II 4.9 & $34 \cdot 0$ \\
\hline 7 & 103 & I3I $\cdot 8$ & II $7 \cdot 7$ & $35 \cdot 2$ \\
\hline 8 & 40 & $136 \cdot 8$ & $122 \cdot 8$ & $36 \cdot 0$ \\
\hline 9 & 40 & I 37.9 & $124 \cdot 0$ & $36 \cdot 9$ \\
\hline I0 & I6 & $\mathrm{I} 42 \cdot 8$ & $127 \cdot 2$ & 38.9 \\
\hline II & I 4 & $\mathrm{I} 42 \cdot \mathrm{I}$ & $126 \cdot 8$ & $38 \cdot 6$ \\
\hline 12 & 8 & $\mathrm{I} 48 \cdot \mathrm{I}$ & I34:4 & $4 \mathrm{r} \cdot 8$ \\
\hline \multicolumn{5}{|c|}{ Spring-spawned scallops } \\
\hline I & 28 & $37 \cdot 5$ & $35 \cdot 7$ & $10 \cdot 4$ \\
\hline 2 & 49 & $73 \cdot 3$ & $67 \cdot 7$ & I9. I \\
\hline 3 & 64 & 98.0 & $90 \cdot 0$ & 26.0 \\
\hline 4 & 48 & II 4.7 & IO4.8 & $30 \cdot 8$ \\
\hline 5 & II & II 8.9 & 107.0 & $30 \cdot 7$ \\
\hline 6 & 8 & $134 \cdot 4$ & $120 \cdot 6$ & 35.8 \\
\hline 7 & 3 & $134 \cdot 2$ & I 15.8 & $36 \cdot 3$ \\
\hline 8 & 6 & $140 \cdot 8$ & $124 \cdot 2$ & $36 \cdot 3$ \\
\hline
\end{tabular}

The second method has several disadvantages. The dimensions at the end of a particular growth period can be obtained only by measuring scallops of that particular age; it is dependent on small-mesh dredge samples for younger scallops, and even then few are caught (see later, p. 490); and it must use scallops caught during the cessation of growth. In the first method, on the other hand, all the growth-rings can be measured on every shell; scallops from the commercial dredge can be used, since information about the early years of the scallop's life can be obtained from older shells; and scallops caught at any time of the year can be used.

In the first method, data from scallops of different year-classes are grouped together, thereby masking any variation in growth rate there may be from year to year. Such variation could be shown by measuring one particular growth-band, say the third, in scallops of all ages in one particular season. 

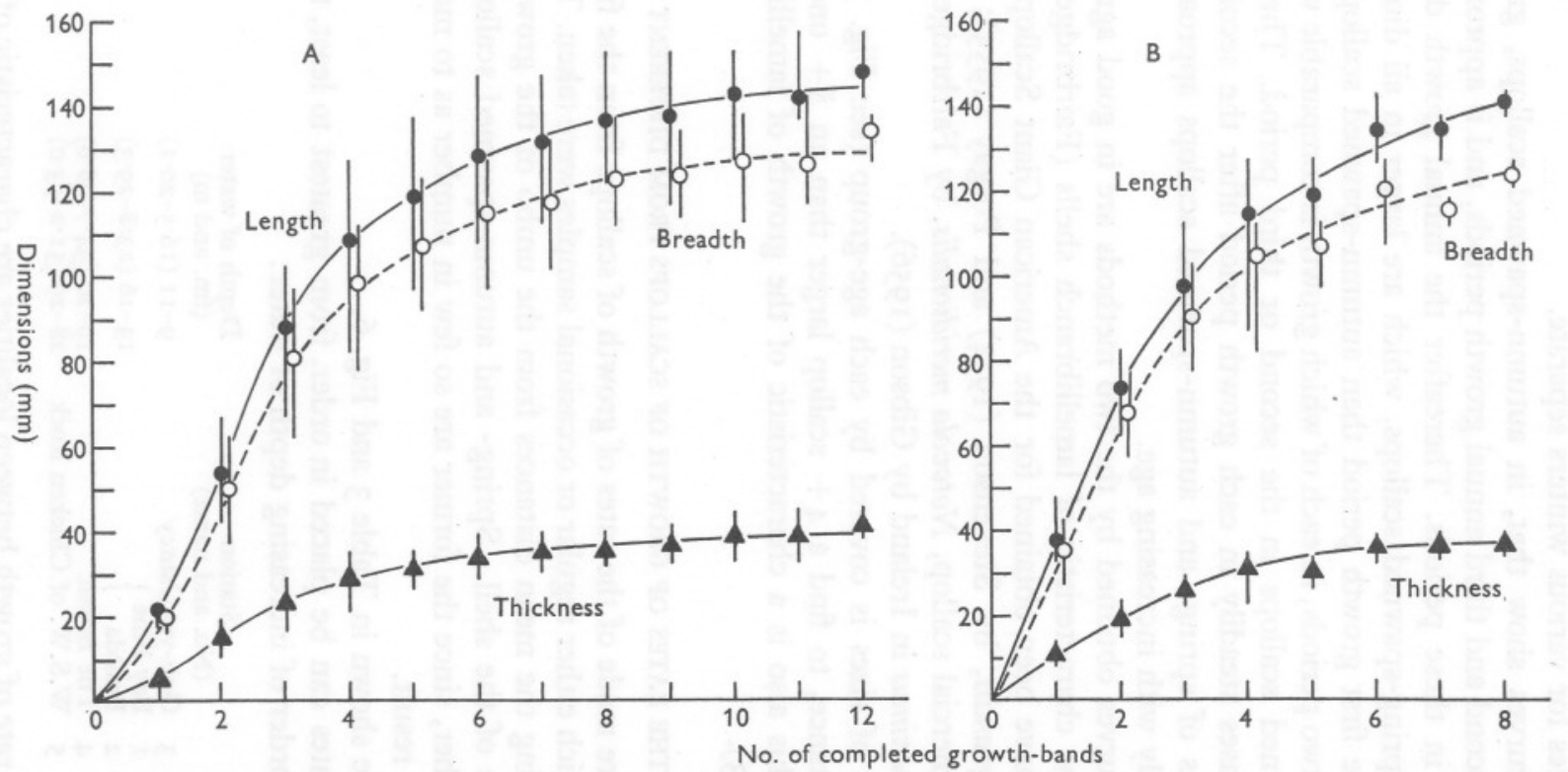

Fig. 5. Length, breadth and thickness of scallops of various ages measured during the cessation of growth. Vertical lines represent the range of sizes in each age-group. Data for breadth are displaced slightly to avoid confusion with length data. (A) Autumn-spawned scallops. (B) Spring-spawned scallops. 
The second method would also afford a means of comparing the rates of growth in different years if sufficient scallops were measured to allow of keeping the figures for various winters separate.

The growth curves show that, in autumn-spawned scallops, growth is greatest in the second and third annual growth periods, and is approximately equal in extent in these periods. Thereafter the annual growth decreases progressively. Spring-spawned scallops, which are larger in all dimensions at the end of the first growth period than autumn-spawned scallops, grow most in the first two periods, in each of which growth is comparable with that of autumn-spawned scallops in the second or third period. The annual increment decreases steadily in each growth period after the second. The mean dimensions of spring- and autumn-spawned scallops approach each other more closely with increasing age.

The growth curves obtained by the two methods are in good agreement, and are of a type characteristic of lamellibranch shells (Fairbridge, 1953). Similar curves have been obtained for the American Giant Scallop, Placopecten (Pecten) grandis, by Stevenson (1934) and Posgay (1953); for the Tasmanian commercial scallop, Notovola meridionalis, by Fairbridge (1953); and for Pecten maximus in Ireland by Gibson (1956).

A large range of sizes is covered by each age-group (see Fig. 5); it is possible, for instance, to find a $4+$ scallop larger than an $8+$ one in the same sample. This also is a characteristic of the growth of lamellibranchs (Fairbridge, 1953).

\section{COMPARISON OF THE RATES OF GROWTH OF SCALLOPS FROM DIFFERENT DEPTHS}

Comparisons were made of the rates of growth of scallops from the five areas (p. 473) from which either regular or occasional samples were taken. This was done by measuring the mean distances from the umbo of the growth-rings on the flat valve of the shell. Spring- and autumn-spawned scallops were considered together, since the former are so few in number as to make little difference to the result.

The results are shown in Table 3 and Fig. 6.

The growth rates can be placed in order, from greatest to least, to correspond with the order of increasing depth of water:

$$
\begin{array}{llc} 
& \multicolumn{1}{c}{\begin{array}{c}
\text { Station } \\
\text { (No. and name) }
\end{array}} & \begin{array}{c}
\text { Depth of water } \\
\text { (fm. and m) }
\end{array} \\
3 & \text { Gob-yn-Ushtey } & 9-1 \mathrm{I}(\mathrm{I} 6 \cdot 5-20 \cdot \mathrm{I}) \\
\text { I } & \text { Bay Fine } & 13-16(23 \cdot 8-29 \cdot 3) \\
2 & \text { Bradda } & 19-20(34 \cdot 7-36 \cdot 6) \\
4 & \text { The Breast } & \text { 19-3 } \\
5 & \text { W.S.W. of Chicken Rock } & 28-29(5 \mathrm{I} \cdot 2-53 \cdot 0)
\end{array}
$$

Differences in rate of growth between localities are characteristic of lamellibranchs (Fairbridge, 1953). Several factors have been suggested to account for local differences of growth rate in pectinid and other molluscan species, 
TABLE 3. MEAN DISTANCES FROM THE UMBO OF GROWTH-RINGS ON THE FLAT VALVE OF THE SHELL

(Spring- and autumn-spawned scallops combined.)

Bay Fine (Stn. I)
Bradda (Stn. 2)
Gob-yn-Ushtey (Stn. 3)
Breast (Stn. 4)
Chicken (Stn. 5)

Number measured
Mean distance $(\mathrm{mm})$
Number measured
Mean distance $(\mathrm{mm})$
Number measured
Mean distance $(\mathrm{mm})$
Number measured
Mean distance $(\mathrm{mm})$
Number measured
Mean distance $(\mathrm{mm})$

\begin{tabular}{cccccccccc}
\multicolumn{10}{c}{ Growth-rings } \\
I & 2 & 3 & 4 & 5 & 6 & 7 & 8 & 9 & 10 \\
1977 & 1732 & 1385 & 1013 & 633 & 277 & 108 & 51 & 22 & 12 \\
$19 \cdot 6$ & $48 \cdot 4$ & $76 \cdot 6$ & $94 \cdot 8$ & $105 \cdot 2$ & $112 \cdot 7$ & $118 \cdot 3$ & $123 \cdot 1$ & $125 \cdot 4$ & $128 \cdot 4$ \\
2402 & 2034 & 1547 & 935 & 529 & 274 & 117 & 90 & 51 & 31 \\
$20 \cdot 8$ & $49 \cdot 9$ & $77 \cdot 2$ & $94 \cdot 7$ & $104 \cdot 7$ & $112 \cdot 0$ & $110 \cdot 4$ & $116 \cdot 9$ & $119 \cdot 5$ & $121 \cdot 9$ \\
117 & 117 & 100 & 96 & 91 & 75 & 62 & 40 & 11 & 10 \\
$22 \cdot 3$ & $54 \cdot 8$ & $83 \cdot 9$ & $102 \cdot 3$ & $112 \cdot 6$ & $118 \cdot 4$ & $122 \cdot 0$ & $124 \cdot 6$ & $129 \cdot 9$ & $132 \cdot 0$ \\
116 & 116 & 114 & 100 & 88 & 48 & 28 & 22 & 11 & 5 \\
$19 \cdot 4$ & $46 \cdot 0$ & $70 \cdot 4$ & $87 \cdot 5$ & $96 \cdot 7$ & $103 \cdot 2$ & $109 \cdot 3$ & $112 \cdot 3$ & $114 \cdot 7$ & $117 \cdot 5$ \\
100 & 100 & 100 & 100 & 100 & 93 & 85 & 58 & 28 & 27 \\
$18 \cdot 7$ & $39 \cdot 8$ & $62 \cdot 4$ & $82 \cdot 0$ & $95 \cdot 1$ & $101 \cdot 8$ & $105 \cdot 5$ & $108 \cdot 9$ & $110 \cdot 7$ & $111 \cdot 5$
\end{tabular}


including currents (Gutsell, 1930; Fairbridge, 1953), temperature (Coe \& Fox, 1944) and the nature of the sea bed (Fairbridge, 1953).

Gibson (1956) found that scallops living on sheltered beds grew more quickly than those on exposed beds, and suggested that this is due to excessive particle bombardment interfering with feeding on the latter beds. This could not be the cause of the differences in growth rate between different areas in the present study, since all the areas were exposed.

In the present study, scallops living in the shallowest water were found to grow more quickly than those in deeper water. It is suggested below (p. 489) that the growth of $P$. maximus is influenced by temperature. It is of interest

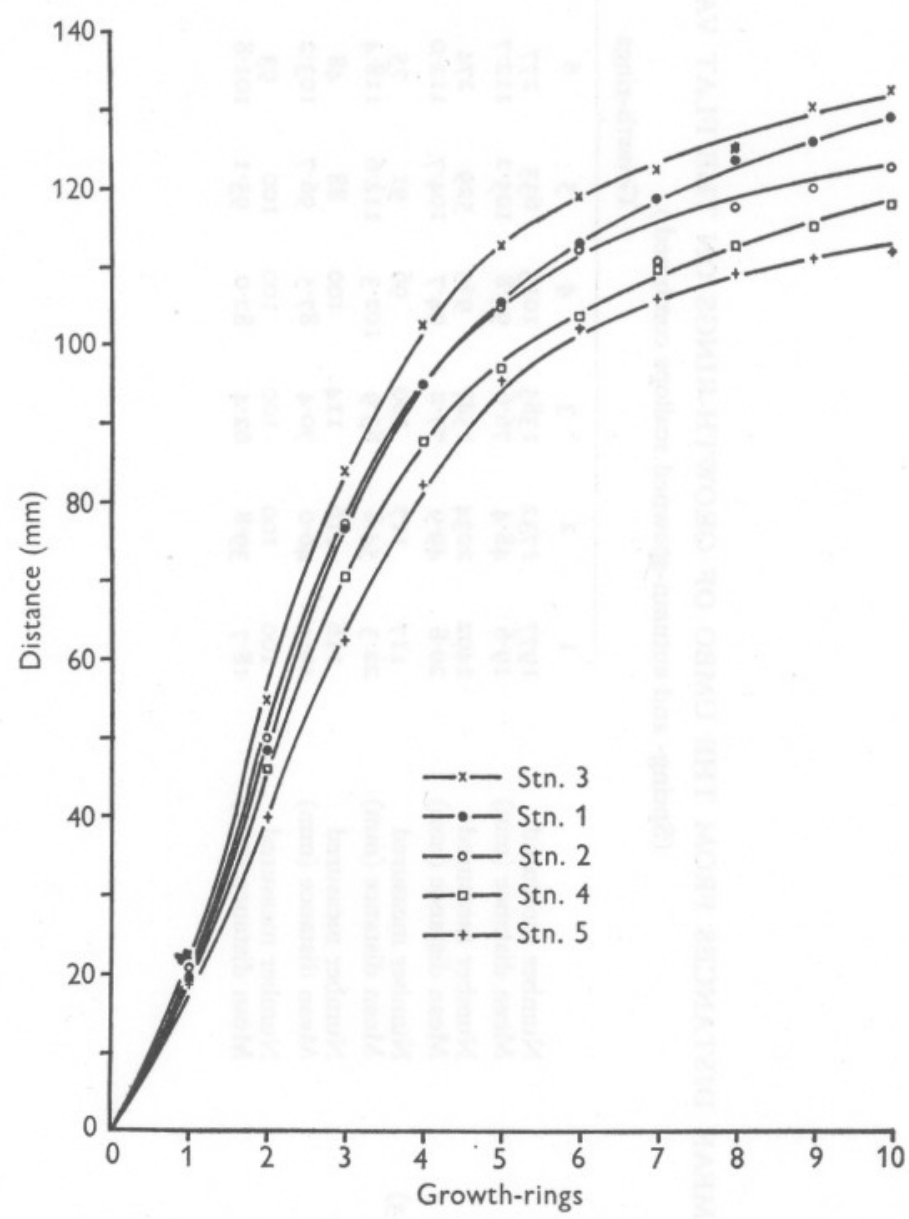

Fig. 6. A comparison of the rates of growth of scallops from five areas (see chart, Fig. I). The graph shows the mean distances from the umbo of the growth-rings on the flat valve of the shell. Data for spring- and autumn-spawned scallops are combined. 
in this connexion that from May to August, when the scallop is growing most rapidly, bottom temperatures inshore are higher than those offshore, ${ }^{1}$ probably resulting in a higher rate of growth on the shallower, inshore beds.

\section{THE ANNUAL PERIOD OF GROWTH}

The period of growth was determined by measuring throughout the year the width of shell outside the outermost growth-ring on the flat valve of the shell of Bradda scallops, spring- and autumn-spawned scallops being treated separately. Autumn-spawned scallops with o-5 growth-rings were used, but insufficient spring-spawned scallops were obtained with more than three rings. Since the annual growth-ring is laid down some time in March, April or May, it is necessary to consider the period March I95I-May 1952 in order to cover a complete growth period. The monthly measurements are, where necessary, reinforced by data from the corresponding month of the other year. Samples taken in the small-mesh dredges were used, supplemented in the larger sizes by scallops from commercial samples.

The results (Table 4 and Fig. 7) show that growth commences in March, April or May, and is most rapid from June to September or October, when it begins to slow down, stopping altogether from December until the following March, April or May. These results agree well with those of Gibson (1956), who found that growth of $P$. maximus in Irish waters ceases from November to February.

With two exceptions, all the scallops which had not yet deposited their first growth-ring were obtained between December and May, after the completion of their early growth. The exceptions were two scallops, 3.5 and $3.0 \mathrm{~mm}$ long, which were found on the Bradda bed in August 1952. These probably arose from the small spawning of July I952, but since this is not certain they were not included in Table 4 and Fig. 7. No suggestion can be advanced at present to explain my inability to find more young specimens; Elmhirst (1945) found many between 0.7 and $4.0 \mathrm{~mm}$ attached to Laminaria saccharina in the Firth of Clyde in July and August.

\section{POSSIBLE FACTORS CAUSING CESSATION OF GROWTH AND THE DEPOSITION OF THE ANNUAL RING}

The growth of an animal is the total result of many interacting factors, of which temperature is well known to be important. With scallops, Belding (I93I) found that growth of Pecten irradians ceased during the cold winter months, and was resumed in May when the temperature of the water had reached $45-50^{\circ} \mathrm{F}\left(7-10^{\circ} \mathrm{C}\right)$. But other factors may have to be taken into account-for instance alternate scarcity and abundance of food (see Thompson, I942). It has been suggested that in P.irradians, cessatian of growth is caused in

${ }^{1}$ Data kindly provided by Mr D. J. Slinn. The temperatures were taken on the Bay Fine bed and at a position near the Chicken Rock bed (Station 5). 
TABLE 4. GROWTH OF SHELL (IN MM) BEYOND THE LAST-FORMED ANNUAL RING, THROUGHOUT THE YEAR

Number of

growth-rings

\begin{tabular}{|c|c|}
\hline 0 & $\begin{array}{l}\text { Number measured } \\
\text { Mean growth }\end{array}$ \\
\hline I & $\begin{array}{l}\text { Number measured } \\
\text { Mean growth }\end{array}$ \\
\hline 2 & $\begin{array}{l}\text { Number measured } \\
\text { Mean growth }\end{array}$ \\
\hline & $\begin{array}{l}\text { Number measured } \\
\text { Mean growth }\end{array}$ \\
\hline & $\begin{array}{l}\text { Number measured } \\
\text { Mean growth }\end{array}$ \\
\hline & $\begin{array}{l}\text { Number measured } \\
\text { Mean growth }\end{array}$ \\
\hline & $\begin{array}{l}\text { Number measured } \\
\text { Mean growth }\end{array}$ \\
\hline & $\begin{array}{l}\text { Number measured } \\
\text { Mean growth }\end{array}$ \\
\hline & $\begin{array}{l}\text { Number measured } \\
\text { Mean growth }\end{array}$ \\
\hline & $\begin{array}{l}\text { Number measured } \\
\text { Mean growth }\end{array}$ \\
\hline
\end{tabular}
Autumn-spawned scallops, age-groups o to 5

$\begin{array}{rrrrrrrrrrrrrrr}Z & - & - & - & - & - & - & - & - & 1 & 1 & 2 & - & - & 4 \\ - & - & - & - & - & - & - & - & - & 19 \cdot 5 & 15 \cdot 5 & 20 \cdot 5 & - & - & 22 \cdot 3 \\ - & - & - & 4 & - & 2 & 3 & 3 & 9 & 9 & 6 & 12 & 31 & 7 & - \\ - & - & - & 9 \cdot 5 & - & 22 \cdot 5 & 24 \cdot 0 & 26 \cdot 0 & 30 \cdot 4 & 31 \cdot 9 & 30 \cdot 7 & 31 \cdot 2 & 30 \cdot 1 & 31 \cdot 3 & - \\ I & 27 & 38 & 20 & 15 & 8 & 9 & 7 & 35 & 5 & 9 & 50 & 5 & 37 & 12 \\ 1 \cdot 0 & 2 \cdot 2 & 4 \cdot 9 & 7 \cdot 9 & 12 \cdot 7 & 18 \cdot 8 & 21 \cdot 3 & 25 \cdot 0 & 27 \cdot 5 & 28 \cdot 4 & 30 \cdot 1 & 30 \cdot 4 & 30 \cdot 4 & 30 \cdot 9 & 30 \cdot 0 \\ 3 & 24 & 74 & 127 & 36 & 17 & 80 & 66 & 52 & 19 & 45 & 90 & 49 & 45 & 9 \\ 2 \cdot 0 & 1 \cdot 9 & 2 \cdot 9 & 4 \cdot 6 & 7 \cdot 6 & 11 \cdot 5 & 14 \cdot 1 & 15 \cdot 9 & 17 \cdot 8 & 18 \cdot 8 & 17 \cdot 8 & 18 \cdot 0 & 18 \cdot 6 & 18 \cdot 9 & 18 \cdot 5 \\ - & 29 & 49 & 52 & 16 & 8 & 13 & 24 & 9 & 8 & 16 & 12 & 13 & 5 & 22 \\ - & 2 \cdot 0 & 1 \cdot 7 & 2 \cdot 3 & 5 \cdot 2 & 6 \cdot 3 & 9 \cdot 4 & 10 \cdot 4 & 12 \cdot 2 & 11 \cdot 4 & 11 \cdot 6 & 12 \cdot 2 & 12 \cdot 0 & 13 \cdot 6 & 10 \cdot 7 \\ - & 3 & 12 & 58 & 43 & 27 & 22 & 20 & 32 & 9 & 35 & 22 & 21 & 33 & 16 \\ - & 0 \cdot 3 & 1 \cdot 5 & 1 \cdot 6 & 3 \cdot 3 & 4 \cdot 4 & 5 \cdot 0 & 6 \cdot 2 & 7 \cdot 5 & 7 \cdot 1 & 7 \cdot 3 & 6 \cdot 8 & 7 \cdot 8 & 7 \cdot 8 & 7 \cdot 3\end{array}$

Spring-spawned scallops, age-groups o to 3

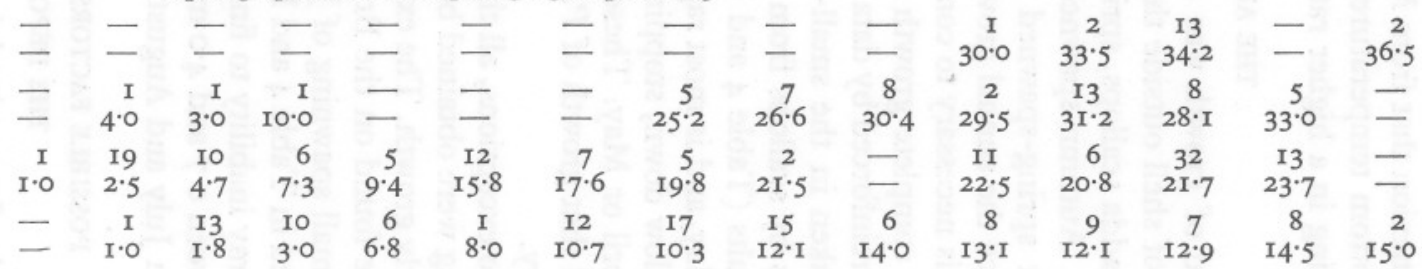


Rhode Island waters by spawning (Risser, I90I), and in North Carolina waters by gonad development (Gutsell, 1930). Gonad development is also suggested in Chlamys varia (Dalmon, 1935) and in Notovola meridionalis (Fairbridge, 1953). Tang (194I), working on Pecten maximus at Port Erin, assumed that the growth-ring which was laid down in April, May or June represented not the resumption but the cessation of growth. Finding more than $50 \%$ of scallops with running gonads in these months, he stated, erroneously, that the cause
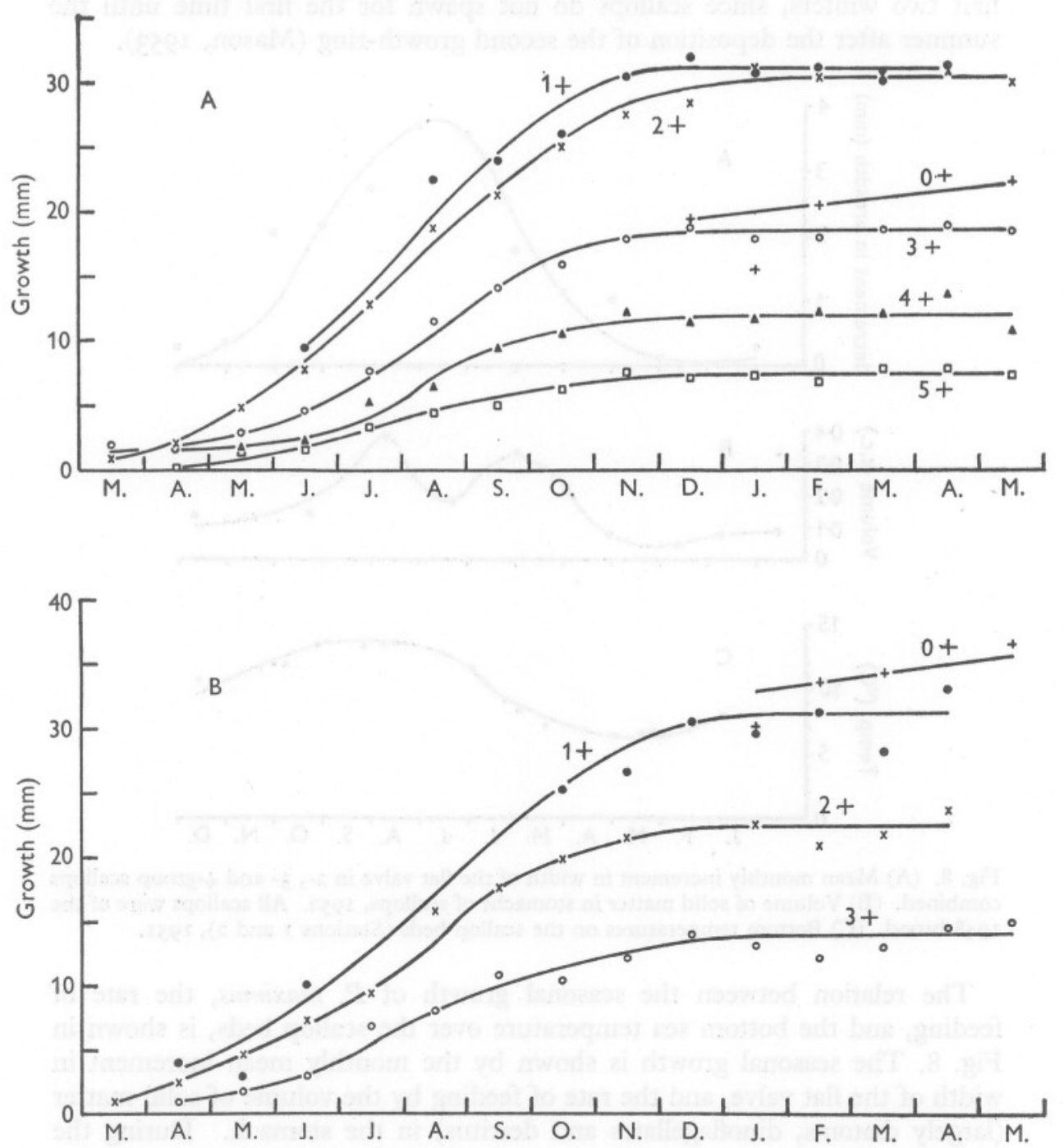

Fig. 7. Growth of shell (in $\mathrm{mm}$ ) beyond the last-formed annual ring, throughout the year. (A) Autumn-spawned scallops, age-groups 0-5. (B) Spring-spawned scallops, age-groups o-3. 
of cessation of growth may be correlated with the poor condition after the formation of gametes and spawning.

Spawning cannot be an effective factor in causing the cessation of growth of P. maximus, since spawning occurs in April or May and in July, August and September, all during the period of growth, while growth ceases from December to March, during which period there is no spawning. Spawning cannot possibly be responsible for the cessations of growth in the animal's first two winters, since scallops do not spawn for the first time until the summer after the deposition of the second growth-ring (Mason, I953).
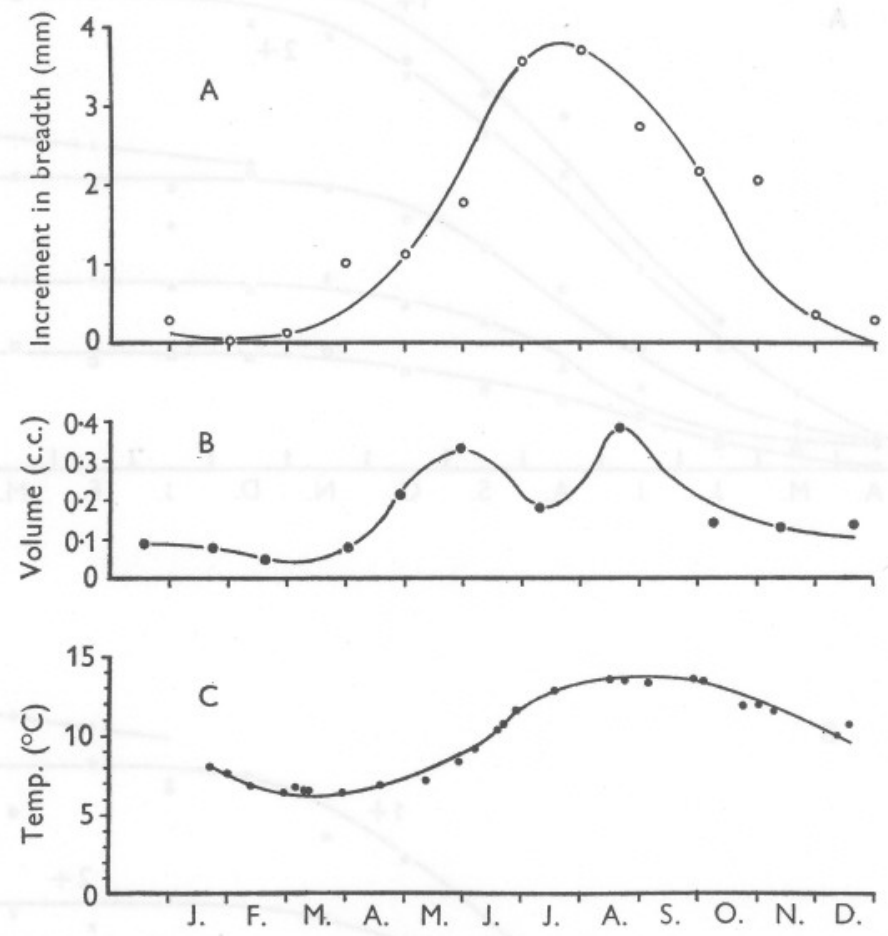

Fig. 8. (A) Mean monthly increment in width of the flat valve in 2-, 3- and 4-group scallops combined. (B) Volume of solid matter in stomachs of scallops, I952. All scallops were of the I948 brood. (C) Bottom temperatures on the scallop beds (Stations I and 2), I95I.

The relation between the seasonal growth of $P$. maximus, the rate of feeding, and the bottom sea temperature over the scallop beds, is shown in Fig. 8. The seasonal growth is shown by the monthly mean increment in width of the flat valve, and the rate of feeding by the volume of solid matter (largely diatoms, dinoflagellates and detritus) in the stomach. During the cessation of growth, the sea temperature is at its annual minimum, and the rate of feeding is at its lowest. The latter may be due to cold, to lack of 
available food, or to both. Gonad development occurs throughout the year, but most slowly in winter, possibly owing to low temperature, low rate of feeding, or both.

It is likely that several factors act together to cause the annual cessation of growth of Pecten maximus. The following hypothesis is tentatively suggested. During the cold of winter, body processes occur slowly, and feeding is sufficient for slow gonad development, but not growth, to occur. With the higher temperature of summer the body processes are speeded up, and feeding is sufficiently high for more rapid gonad development and also growth to occur, even during the slight drop in feeding in July. (Too much significance should probably not be attached to the July minimum, as only one sample of stomach contents was obtained between May and August.)

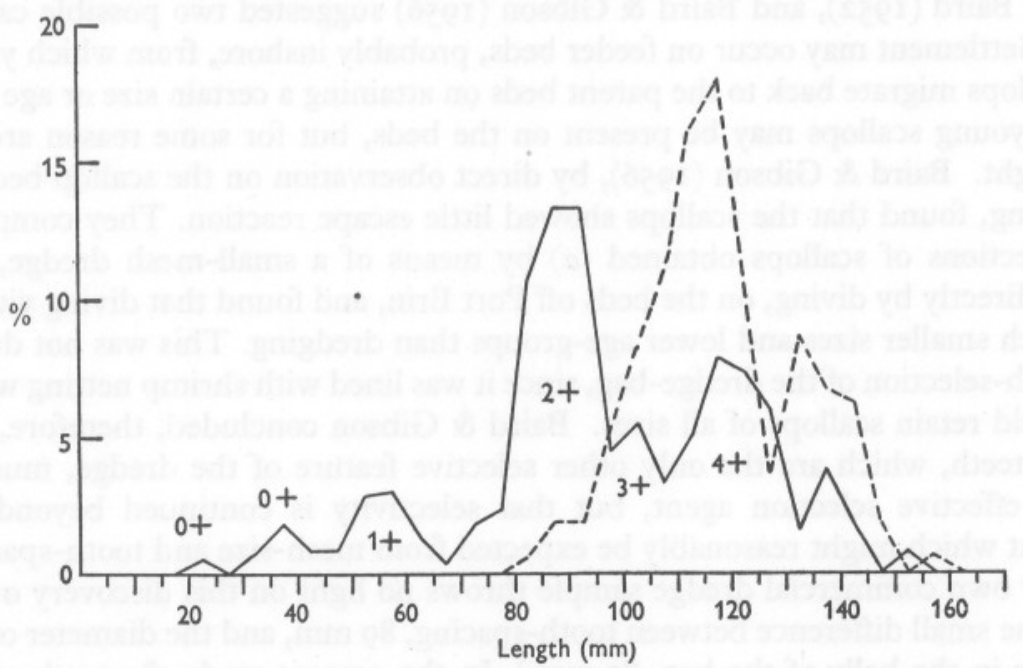

Fig. 9. Length-frequency of Bradda scallops in samples; March I95I. R.V. William Herdman. Length in $5 \mathrm{~mm}$ groups. $\longrightarrow, 4 \mathrm{ft}$. small-mesh dredge (398 scallops measured); $-\ldots, 6 \mathrm{ft}$. commercial dredge (I6I scallops measured).

\section{LENGTH-FREQUENCY AND THE SCARCITY OF YOUNG SCALLOPS}

Comparisons were made of the length-frequencies of scallops taken in the $6 \mathrm{ft}$. commercial and $4 \mathrm{ft}$. small-mesh dredges (see above, p. 473) on the Bradda bed by R.V. William Herdman in March I95I (Fig. 9). The samples were made up of the contents of several dredge hauls, each of 15 min duration in the case of the commercial dredge, and of $7 \mathrm{~min}$ duration in the case of the small-mesh dredge, which quickly filled with gravel and shells.

The commercial dredge, which is typical of Manx commercial scallop dredges, exercises a selective action, which begins to act at $95-100 \mathrm{~mm}$ (Fig. 9). There is no selection of scallops more than $100 \mathrm{~mm}$ long, but few less than $95 \mathrm{~mm}$ long are taken. None less than $80 \mathrm{~mm}$ long was caught in 
March 1951, but the commercial dredge occasionally retained a few smaller scallops among the stones and shells in the bag. On the average the scallop attains a size of $100 \mathrm{~mm}$ late in its fourth growth period, so that most scallops spawn in at least two years before they can be caught.

The length-frequency curve for the small-mesh dredge shows a number of peaks, of which the first few each consist entirely or almost entirely of scallops of one age-group (Fig. 9). The most abundant age-group in the sample was that composed of scallops with two growth-rings. It would be expected that the youngest scallops would be most abundant, decreasing in abundance with increasing age. The contrary results appeared to imply that a proportion of the younger, and therefore smaller, scallops, was being missed.

A scarcity of young scallops in dredge samples was noted also by Priol (1930) and Baird (1952), and Baird \& Gibson (1956) suggested two possible causes. (i) Settlement may occur on feeder beds, probably inshore, from which young scallops migrate back to the parent beds on attaining a certain size or age; and (ii) young scallops may be present on the beds, but for some reason are not caught. Baird \& Gibson (1956), by direct observation on the scallop beds by diving, found that the scallops showed little escape reaction. They compared collections of scallops obtained $(a)$ by means of a small-mesh dredge, and (b) directly by diving, on the beds off Port Erin, and found that diving yielded much smaller sizes and lower age-groups than dredging. This was not due to mesh-selection of the dredge-bag, since it was lined with shrimp netting which would retain scallops of all sizes. Baird \& Gibson concluded, therefore, that the teeth, which are the only other selective feature of the dredge, must be the effective selection agent, but that selectivity is continued beyond the point which might reasonably be expected from mesh-size and tooth-spacing. (My own commercial dredge sample throws no light on this discovery owing to the small difference between tooth-spacing, $89 \mathrm{~mm}$, and the diameter of the rings in the belly of the bag, $82 \mathrm{~mm}$.) In the present study the teeth of the small-mesh dredge must have dug deep into the sea bottom, since the bag rapidly became full of fine gravel, shells, stones and other objects. This means that the teeth were ineffective as a selective agent, and the dredge acted as a complete bottom-sampler. Even so it collected less than the expected proportion of young $(\mathrm{O}+$ and $\mathrm{I}+)$ scallops. In fact my small-mesh dredge sample compared closely with the sample collected by hand, from visual observation, by Baird \& Gibson. It would appear, therefore, that fewer o+ and $\mathrm{I}+$ scallops than expected are actually on the beds.

As Baird \& Gibson pointed out, few o + scallops would be expected in their collections, which were taken in July 1953, since 90-95\% of scallops at Port Erin are autumn-spawned. It is still difficult, however, to account for the relative shortage of I + scallops in Baird's \& Gibson's collections and of o+ and $\mathrm{I}+$ scallops in my small-mesh dredge samples taken in March and at all other times of the year. 
This paper is based on parts of a thesis ${ }^{1}$ presented to the University of Liverpool in 1953 for the degree of Ph.D. The work was carried out at the Marine Biological Station, Port Erin, while I held a Herdman Studentship and Liverpool University Research Fellowship. I wish to thank the Director, $\mathrm{Mr}$ J. S. Colman, for suggesting the problem to me, for his constant guidance and valuable criticisms, and for reading the manuscript. $\mathrm{Mr} \mathrm{A}$. B. Bowers and $\mathrm{Mr}$ A. D. McIntyre also read the manuscript and made helpful suggestions. I am grateful for the help given by the scientific staff, students and technical staff of the Marine Biological Station, particularly by Mrs D. I. Williamson and Miss M. MacLeod. Lastly, I wish to thank the Masters and crews of the R.V. William Herdman and the M.B.'s Cypris and Runa.

\section{SUMMARY}

Growth-rings on the shell of the scallop (Pecten maximus) are laid down annually, in spring, and so can be used to determine the age.

Scallops grow from spring to December, and cease growing in winter. The resumption of growth in the spring is marked by the appearance of the annual growth-ring at the edge of the shell.

The first year's growth is of one of two types. A few scallops have shells which show a large first year's growth, $28 \mathrm{~mm}$ or more wide, while the great majority have shells which show a small first year's growth, less than $28 \mathrm{~mm}$ wide. These two types probably depend on the two principal spawning periods of the scallop, most of the former arising from the spring spawning and most of the latter from the autumn one.

The growth curve of $P$. maximus is of a type characteristic of lamellibranch shells. The annual growth is greatest in the first two or three years of life, after which it decreases steadily.

Scallops grow more quickly in shallow water than in deeper water.

Possible causes of the annual cessation of growth are discussed.

A paucity of young scallops was noted in the dredge samples, as previous workers have reported. No reason can be given.

\section{REFERENCES}

BaIrd, R. H., 1952. The English Channel escallop beds. Fishing News, No. 2064, p. 9 .

BAIRD, R. H. \& Gibson, F. A., 1956. Underwater observations on escallop (Pecten maximus L.) beds. F. mar. biol. Ass. U.K., Vol. 35, pp. 555-62.

Belding, D. L., I9Io. A Report upon the Scallop Fishery of Massachusetts. Boston: Commonwealth of Massachusetts.

- 193I. The Scallop Fishery of Massachusetts. Boston: Comm. Mass., Dept. Cons. [An abbreviated reprint of the I9I0 paper.]

1 'Investigations on the scallop [P. maximus (L.)] in Manx waters', 1953. 
Coe, W. R. \& Fox, D. L., 1944. Biology of the California sea-mussel (Mytilus californianus). III. Environmental conditions and rate of growth. Biol. Bull., Woods Hole, Vol. 87, No. I, pp. 59-72.

Coker, R. E., SHIRA, A. F., Clark, H. W. \& Howard, A. D., I92I. Natural history and propagation of freshwater mussels. Bull. U.S. Bur. Fish., Vol. 37, pp. 75I8I.

Dakin, W. J., 1909. Pecten. L.M.B.C. Mem., No. I7.

Dalmon, J., I935. Note sur la biologie du pétoncle (Chlamys varia L.). Rev. Trav. Off. Pêches marit., T. 8, pp. 268-8I.

Elmhirst, R., I945. Clam fishing in the Firth of Clyde. Trans. Butesh. nat. Hist. Soc., Vol. I3, pp. II3-I6.

FAIRBRIDGE, W. S., I953. A population study of the Tasmanian 'commercial' scallop, Notovola meridionalis (Tate) (Lammellibranchiata, Pectinidae). Aust. F. mar. freshw. Res., Vol. 4, No. I, pp. I-40.

Gibson, F. A., 1956. Escallops (Pecten maximus L.) in Irish waters. Sci. Proc. R. Dublin Soc., Vol. 27, pp. 253-70.

Gutsell, J. S., I930. Natural history of the bay scallop (Pecten irradians). Bull. U.S. Bur. Fish., Vol. 46, pp. 569-632.

Posgay, J. A., I953. The sea scallop fishery. 6th Report on Investigations of the Shellfisheries of Massachusetts. Boston: Comm. Mass., Dept. nat. Resour. Div. mar. Fish.

Priol, E., 1930. La coquille Saint-Jacques (Pecten maximus). Rev. Trav. Off. Pêches marit., T. 3, pp. I43-73.

Risser, J., I90I. Habits and life-history of the scallop (Pecten irradians). Rep. R. I. Comm. inl. Fish., Year 31, pp. 47-55.

Stevenson, J. A., I934. The growth-rate of Canadian scallops. Progr. Rep. Atl. biol. Sta., No. II, pp. IO-II.

TANG, S.-F., I94I. The breeding of the escallop [Pecten maximus (L.)] with a note on the growth rate. Proc. Lpool biol. Soc., Vol. 54, pp. 9-28.

Thompson, D’A. W., 1942. On Growth and Form. III6 pp. Cambridge University Press. 